\title{
Арумынский язык в Преспанском регионе (Республика Македония) сегодня*
}

\author{
ДАРЬЯ КОНЁР, АНАСТАСИЯ МАКАРОВА \\ Институт лингвистических исследований Российской академии наук, \\ Тучков пер., д. 9, RU-199053 Санкт-Петербург \\ E-mail: dsuetina@yandex.ru, abeatina@rambler.ru
}

(Received: 7 June 2017; accepted: 5 September 2017)

\begin{abstract}
The aim of the paper is to describe the language situation and the main features of the Aromanian dialect in the Prespa region. The ethnolinguistic group of Aromanians is represented in this region only by one family. Nowadays, this linguistic situation is an example of language death, as the younger generation no longer speaks the Aromanian language whereas the senior generation uses it in limited contexts. The Aromanian speech abounds with multiple examples of interference of Macedonian, which is the dominant language in relation to Aromanian in this situation. The Aromanian language is still used on a daily basis; however, it is spoken only by the senior members of the language community. We suppose that in this situation, there is little chance for the Aromanian language to experience its renaissance in Prespa.

Keywords: Aromanian language, Prespa Lake Region, Macedonia, language contact, language death, Balkan migration
\end{abstract}

Цель настоящей статьи - описать языковую ситуацию и основные черты диалекта арумын региона Преспа. Этноязыковая группа арумын представлена в данном регионе только одной семьей. Данная языковая ситуация рассматривается как пример «языковой смерти», так как младшее поколение уже не владеет арумынским языком, а старшее употребляет его только в ограниченных контекстах. Арумынская речь изобилует многочисленными примерами интерференции македонского языка, являющегося доминантным по отношению к арумынскому в данной ситуации.

\section{1. Введение}

Массовое и планомерное продвижение романского и романизированного населения в глубь Балканского полуострова произошло в III-IV вв. н. э. Оно проходило широкой полосой от побережья Адриатики (напротив Апулии) на северо-восток вдоль долин рек Дрина, Ибр, Морава и до Дуная. На юге проживало грекоязычное и эллинизированное население, на северозападе - иллирийские скотоводческие племена. Часть из них, как считается,

* Исследование выполнено за счет гранта Российского научного фонда (проект «От сепарации до симбиоза: языки и культуры Юго-Восточной Европы в контакте», № 14-18-01405). 
постепенно романизировалась (предки арумын-фаршеротов и мегленорумын), часть - эллинизировалась (возможно, предки саракачан), часть была славянизирована (один из этногенетических компонентов черногорцев и македонцев), представители некоторых племен сохранили свой язык и стали предками албанцев (ШироковА 2005: 186-190, СЕлищев 1931). ${ }^{1}$

Славяне начинают проникать на Балканский полуостров с IV-V вв., и дальнейшее формирование балканороманских языков происходило в тесном контакте романского и славянского этнического элемента (ШироковА 2005: 186-187, ШувАлов 1998, БромЛЕй и др. 1963: 27-41). В результате ряда миграционных волн в VII-VIII вв. на территории современной Черногории, северной Албании и Метохии появилось несколько сербских княжеств, на востоке - Болгарское царство (БРомлЕй и др. 1963: 69-76). Между ними долгое время сохранялась прослойка романоязычного населения, значительная часть которого со временем была славянизирована, другая же, связанная с отгонным скотоводством, - сохранила в значительной степени язык и традиции, что подтверждается исследованиями диалектной лексики балканских языков, где значительная часть терминов, связанных с трансгумацией и молочным производством, имеет романское происхождение (МДАБЯ 2009, ШиРоковА 2005: 187). ${ }^{2}$ В славянских (после обретения славянами письменности в IX в.) и греческих рукописях пастушеское романоязычное население уже тогда начинает появляться под именованием влахи (НАрумов 2001). Их идиом даст начало арумынскому и мегленорумынскому языкам, которые, наряду с дакорумынским и истрорумынским, образуют совокупность балкано-романских (или восточно-романских) языков / макродиалектов (см. Рисунок 1). По мнению лингвистов, все они выделились из проторумынского языка (в свою очередь, развившегося из народной латыни, бытовавшей по обе стороны Дуная) в IX-XI вв. н. э. (см. RoseTti 1986). Характерно отсутствие единого литературного арумынского языка, неоднородность арумынских говоров и значительные языковые различия, наблюдаемые зачастую даже в пределах одного

1 Экспансия Рима на Балканский полуостров началась намного раньше, еще в III в. до н. э., но только к 59 г. до н. э. римлянам удалось укрепиться на северо-западе полуострова и образовать провинцию Иллирия (с 40-х годов - Далмацию, до р. Дрин). Началось планомерное вторжение в глубь страны (ШиРоковА 2005). Об истории завоевания дунайского левобережья (последней из завоеванных провинций и одновременно первой, покинутой римлянами всего лишь через 165 лет после освоения Дакии) см. ЗЛАТковскАя 1951.

2 «Как известно, овца была доместицирована человеком именно на Балканах и уже древнейшее индоевропейское население полуострова - фракийцы и иллирийцы - предположительно практиковало отгонное скотоводство (трансгумацию), используя многочисленные высокогорные пастбища летом и пастбища в долинах зимой в соответствии с периодами вегетации. Для целого ряда балканских регионов перемещать овец (даже если один перегон длится не 8-10 дней, а около месяца) оказывалось выгоднее, чем косить траву или собирать ветви и складировать их в качестве корма на зиму. Этот тип хозяйствования сохранился у балканских скотоводов-номадов и полуномадов (арумын, грекоязычных саракачан, тюркоязычных юруков, части албанцев и части славян, например, мияки в западной Македонии) и в византийский, и в османский период вплоть до окончательной седентаризации в ХХ веке» (МДАБЯ 2009: 3). 
населенного пункта. ${ }^{3}$ Выделяют две основные группы говоров: североарумынские говоры (фаршеротские, москопольские и др.) и южноарумынские говоры (пиндские, грамостянские и др.) (НАрумов 2001). Эти названия связаны с ареалами расселения арумын в прошлом и настоящем, крупнейшими из которых в настоящее время являются: горный массив Пинд (Греция), ряд регионов южной Албании; отдельные поселения существуют также в югозападной Болгарии, Сербии и Румынии; известны и арумынские диаспоры в Западной Европе, США, Австралии (НАРумов 2001).

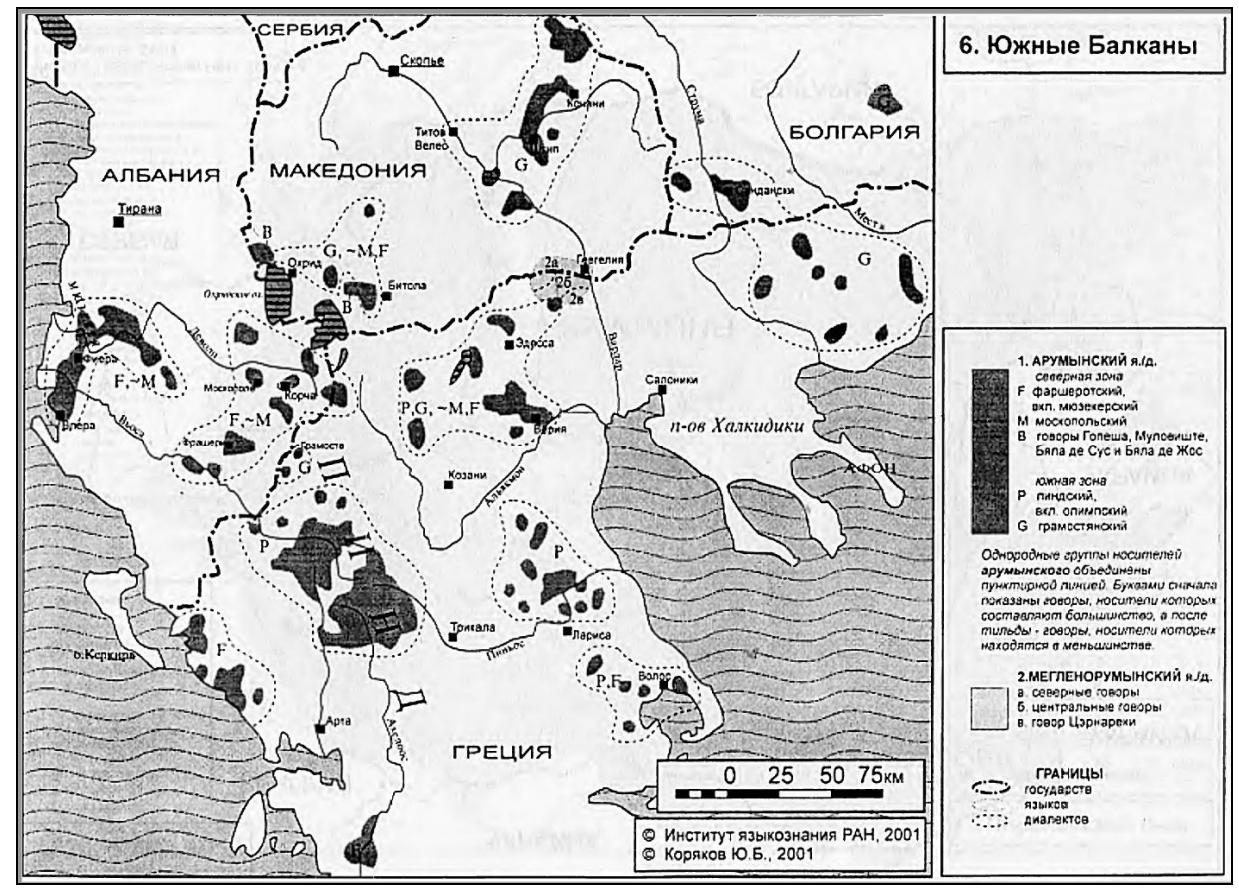

Рисунок 1. Карта распространения арумынского и мегленорумынского языков на Балканах (НАРумов 2001).

${ }^{3}$ В то время как некоторые романисты считают арумынский самостоятельным языком, другие ученые рассматривают его как диалект румынского языка. Во многом дискуссионность места арумынского в балканороманской языковой подгруппе определяется неразрешенной в науке проблемой этногенеза арумынской этнической общности. Романисты, придерживающиеся теории о переселении предков арумын с севера на юг из единого балканороманского ареала (Г. Вайганд, О. Денсушану, А. Филиппиде), склонны считать арумынский одним из диалектов румынского языка. Сторонники автохтонного происхождения арумын в горных областях к югу от Дуная независимого от дакорумын (Т. Папахаджи, Т. Капидан), чаще рассматривают арумынский как самостоятельный язык (НАРумОв 2001). Принимая во внимание как отсутствие полных исторических сведений о балканских миграциях в Средние века, так и четких критериев разграничения понятий «язык» и «диалект», в рамках настоящей статьи мы не будем подробно останавливаться на аргументах каждой из сторон. В данном случае нам кажется корректным применять термин «язык / макродиалект» по отношению к идиомам дакорумын, арумын, мегленорумын и истрорумын. 
Большинство арумын Македонии относится к грамостянам, но там также проживают москопольцы и фаршероты (МАРковиќ 2007). В основном македонские арумыны образуют компактные поселения на юге и юго-востоке страны. Считается, что появление постоянных арумынских (или влашских) населенных пунктов в Западной Македонии произошло только по завершении миграционных волн, начавшихся в 1769 г., ${ }^{4}$ однако многие разрозненные (и зачастую не вполне ясные) источники, в том числе устная традиция, указывают на значительный романоязычный элемент на территории вокруг Охридского и Преспанского озер в византийский период (Кукудис 2013).

\section{2. Арумыны Преспанского региона и их язык}

Локус нашего исследования - полиэтничный регион Преспа, который находится на пересечении границ Македонии, Греции и Албании. В македонской части Преспы живут македонцы, албанцы, арумыны, турки и цыгане (MaKarova 2016). Первое эксплицитное историческое свидетельство об арумынском присутствии в Преспанском регионе датируется 976 г. (в этом году некие «влашские разбойники» убили брата царя Самуила Давида) (см. WiNNIFRITH 1987: 100). Влашские села, расположенные на юго-западе Македонии, в Пелистерском регионе, по всей вероятности, являются одними из самых древних арумынских поселений на территории Вардарской Македонии (Кукудис 2013).

Преспанско-Битольской регион уже с античности и особенно с эпохи раннего Средневековья играл ключевую роль в процессе романизации Балканского полуострова, так как именно там, между городами Ресен и Битола, проходила важнейшая римская дорога Via Egnatia. C XVIII века в регионе обосновалась группа влахов-москополян, которые бежали из разрушенного албанцами-мусульманами в XVIII веке арумынского центра г. Москополе. Местная традиция сообщает, что исконный диалект региона значительно отличался от языка переселенцев. Вайганд объясняет это связью пелистерских влахов с мегленорумынами, некогда переселившимися в область Преспанского и Охридского озер (WeIGAND 1895: 39-40, CVIJÍ́ 1906). Впрочем, к началу XIX века лингвистические различия стерлись вместе с ассимиляцией автохтонного элемента более численной группой москополян.

После завершения миграционных процессов в начале XX века, ${ }^{5}$ арумынское население в области Горна Преспа было сосредоточено в административном центре области Преспа г. Ресен (арум. Areshanj) и в прилегающем к нему селе Янковец (арум. Iankuveț). По статистическим данным конца XIX

\footnotetext{
${ }^{4}$ Имеются в виду массовые миграции москопольцев, бежавших из разрушенного албанцами-мусульманами в XVIII в. арумынского города в южной Албании Москополе в Македонию и северную Грецию. В Охридской области поселилась группа фаршеротов (названных так по южноалбанскому городу Фрашер [Frashër]), основав известные арумынские села Горна и Долна Белица (НАРумов 2001: 638).

${ }^{5}$ Подробную хронологию и библиографию см. Кукудис 2013: 426-456.
} 
века, в нахиях Горна и Долна Преспа насчитывалось 22995 арумын (Кънчов 1900). К северу от Большого Преспанского озера на склонах Галичицы располагались временные пастушеские поселения, используемые в сезон выпаса овец: Горен Исток и Долен Исток (арум. Calivi di Ristoc) (Кукудис 2013).

Переписи населения, проведенные в XX веке, позволяют проследить, как постепенно уменьшалось количество жителей, декларирующих себя как арумыны (ЈовАновски 2005). По данным переписи 2005 года в Ресене и Янковце проживало всего 18 арумын. ${ }^{6}$ Таким образом, регион Преспа, бывший некогда одним из центров как автохтонного арумынского населения, так и местом концентрации влахов, бежавших из Москополе, в течение ста лет полностью утратил свое значение.

В ходе экспедиций мы получили сведения о том, что в г. Ресене и в прилегающем к нему селе Янковец остались только две семьи, в которых говорят на арумынском языке. Кроме того, несколько человек помнят о своем арумынском происхождении, однако уже не владеют языком. По сообщениям местных жителей (как арумын, так и представителей иных этнических групп этого региона), большинство арумынских семей во второй половине XX века переехало в Скопье или за пределы Македонии. Кроме того выяснилось, что одна из двух ресенских арумынских семей также живет за границей и приезжает в Ресен только на отдых. Члены единственной оставшейся арумынской семьи проживают в центре города Ресен и владеют портняжной мастерской, в которой работают отец, мать и сын (дочь вышла замуж и переехала в македонское село Горна Бела Црква). Следует отметить, что муж дочери и жена сына - македонцы, и в их присутствии в семье говорят на македонском. Таким образом, общение на арумынском языке ограничивается узким кругом: родители и двое детей. Представители самого младшего поколения - внуки - арумынским уже не владеют ни активно, ни пассивно.

Итак, арумынский употребляется только в довольно ограниченном речевом контексте семьи и быта, во всех же остальных речевых ситуациях информанты используют македонский. Следовательно, именно македонский является доминирующим, несмотря на то, что для наших информантов он второй по порядку усвоения.

Диалект преспанских влахов до настоящего времени не документировался и не изучался. В 2013-2015 гг. авторами статьи были проведены три экспедиции в данном регионе. Как выяснилось при анализе собранного нами полевого материала, данный идиом разделяет основные фонетические (например, нейтрализация противопоставления фонем /i/, /e/ и дифтонга /ea/ в некоторых позициях, а также неразличение фонем /y/ и /ə/) и грамматические (например, структура глагольной системы) дифференциальные черты с общим по происхождению (также сложившимся на базе языка москопольцев) идиомом арумын Крушево (подробнее об этом диалекте см. GoŁĄв 1984).

\footnotetext{
${ }^{6}$ Всего на территории Республики Македония насчитывается около 9 тыс. арумын (0,4\%, населения) (КАHL 2005).
} 
Специфика собранного материала, а также рамки настоящей статьи не позволяют нам привести полное описание «преспанского арумынского», поэтому мы ограничимся перечислением некоторых наиболее характерных черт данного идиома в балканистической перспективе и в сравнении с дакорумынским языком / макродиалектом. ${ }^{7}$ Отличительной особенностью как идиомов Крушево и Преспы, так и арумынского языка в целом принято считать большое количество грамматических изоморфизмов, находящих свои параллели и в македонском (особенно в его диалектных формах) (МАКАРовА 2016).

\begin{tabular}{|c|c|c|}
\hline & Арумынский & Македонский \\
\hline $\begin{array}{c}\text { «Будущее в прошедшем» } \\
\text { в значении итератива, } \\
\text { образованное с помощью } \\
\text { вспомогательного гла- } \\
\text { гола будущего времени } \\
v a+\text { имперфект } \\
\text { конъюнктива }\end{array}$ & $\begin{array}{l}\text { va s-adra cuziniacuri dulțe } \\
\text { 'готовили сладкие } \\
\text { куличи' } \\
\text { ş-căn va-s zine Hristos } \\
\text { voskrese... } \\
\text { 'И когда начинали nemь } \\
\text { «Христос воскресе»...' }\end{array}$ & $\begin{array}{l}\text { Ќ игравме сите заедно, } \\
\text { ке шетавме. } \\
\text { 'Мы играли все вместе, } \\
\text { гуляли.' }\end{array}$ \\
\hline $\begin{array}{c}\text { Сложный перфект, обра- } \\
\text { зованный с помощью } \\
\text { вспомогательного гла- } \\
\text { гола «иметь» + неизме- } \\
\text { няемая форма причастия } \\
\text { прошедшего времени }\end{array}$ & $\begin{array}{l}\text { Şi noi dădem simiți, simite, } \\
\text { păne, adrată simite, cu } \\
\text { bombone, ş-copte, nuţi, } \\
\text { orevi, căstan'e. } \\
\text { 'И мы давали булочки, } \\
\text { хлеб, делали булочки, } \\
\text { конфеты и печеные } \\
\text { орехи, каштаны.' } \\
\text { ş-раia ți-aveam adunată } \\
\text { 'и приданое мне собрали' }\end{array}$ & $\begin{array}{l}\text { Многу со волна имам ра- } \\
\text { ботено. } \\
\text { 'Я много работала с шер- } \\
\text { стью.' }\end{array}$ \\
\hline
\end{tabular}

Таблица 1. Некоторые примеры грамматического изоморфизма в арумынском и македонском диалектах Преспы ${ }^{9}$

На грамматическом, лексическом и фонетическом уровнях арумынский Преспы содержит многочисленные структурные совпадения с дакорумынскими формами речи, а различия между ними зачастую вызваны сохранением некоторых архаичных черт и моделей в арумынском, с одной стороны, и приобретением инноваций под влиянием контактных языков (прежде всего, греческого и македонского), с другой стороны (GoŁĄв 1984).

Стоит отметить, что в области вокализма и консонантизма основными особенностями арумынского Преспы будут: неразличение звуков [ә] и [i] обозначаемых в румынской письменной традиции $\breve{a}$ и $\hat{a} / \hat{\imath}$ соответственно

\footnotetext{
${ }^{7}$ Подробнее об отличии арумынских диалектов от дакорумынских см. PAPAHAGI 1974 , SARAMANDU-NEVACI 2014.

${ }^{8}$ В наших материалах - как видно в примере из Таблицы 1 - встречается употребление этого перфекта без вспомогательного глагола.

${ }^{9}$ Примеры из таблицы были записаны нами в г. Ресен.
} 


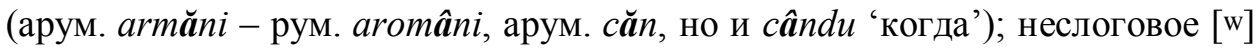
на конце существительных мужского и среднего родов в единственном числе без определенного артикля (арум. prănzu, prănz 'обед', арум. sufletu, suflet

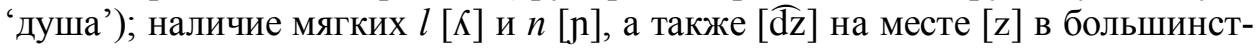
ве случаев в дакорумынском (арум. niți 'маленькие', арум. dzâțim 'говорим',

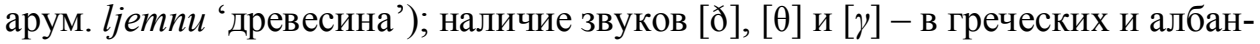

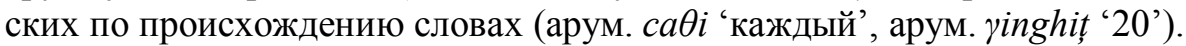

В области морфологии и грамматики в наших материалах встречаются следующие явления: гораздо более частое, чем в дакорумынском, употребление синтетического простого перфекта вместо аналитического сложного (арум. mi mărtai, viniu ația 'я вышла замуж и переехала сюда'); наличие имперфекта конъюнктива; неопределенный артикль женского рода единственного числа ună; применение модели «единица + spre (предлог 'к') + десяток» не только к количественным числительным от 1 до 10, но и от 21 до 29, причем сохранено латинское viginti ‘двадцать' (CAPIDAN 2005: 402-407); отсутствие предлога в конструкциях, обозначающих местонахождение предмета, место действия и направление (арум. s-duc ili Skopje ili Bitule 'едут в Скопье или в Битолу').

Принято говорить о близости синтаксиса в дакорумынских и арумынских формах речи (CAPIDAN 2005: 525-530). Особенности кажущихся нетипичными конструкций нуждаются в более пристальном рассмотрении.

Tora iar închisiră s-aibă.

Pi masă atunțel gheluri s-adra.
'Сейчас вроде опять закрылись.'

'К столу тогда сладкое готовили.'

При работе с использованием различных анкет (фонетической, лексической и грамматической), обнаруживается, что языковая компетенция информантов в арумынском значительно ниже, чем в македонском, особенно когда речь идет о лексическом плане. Работая по анкете, включающей в себя термины, обозначающие части тела, мы установили, что информантам, заданием которых было перевести лексемы с македонского на арумынский, известна только базовая лексика данной семантической группы. Ниже представлен фрагмент заполненной анкеты: ${ }^{10}$

\begin{tabular}{|c|c|c|c|}
\hline Номер & Русский & Македонский $^{11}$ & Арумынский \\
\hline 3.053 & ‘язык’ & јазик & limbă \\
\hline 3.054 & 'небо' & непче & limba/linba \\
\hline 3.055 & 'yxo' & уво & - \\
\hline 3.056 & 'ушная раковина' & ушна школка & urek $^{i}$ \\
\hline
\end{tabular}

${ }^{10}$ Македонские примеры записаны в стандартной орфографии, арумынские - в румынской орфографической традиции.

${ }^{11}$ Слова из этого столбца, которые впоследствии использовались как металексемы при работе с арумынскими информантами, были записаны нами в ходе интервью с Н. Т. 1953 г. р., носительницей македонского преспанского диалекта. 


\begin{tabular}{|c|c|c|c|}
\hline 3.057 & 'мочка уха' & мекото на уво & urekle \\
\hline 3.058 & 'козелок уха' & - & - \\
\hline 3.059 & 'шея' & врат & - \\
\hline 3.060 & ‘передняя часть шеи’ & тил & - \\
\hline 3.061 & ‘задняя часть шеи’ & гуша & guşe \\
\hline 3.062 & ‘горло’ & грло & - \\
\hline 3.063 & ‘кадык’ & петле & - \\
\hline 3.064 & 'волосы (на голове)' & коса & gurmadz \\
\hline 3.065 & ‘борода' & брада & - \\
\hline 3.066 & 'усы’ & мустаќи & perce \\
\hline 3.067 & 'рука' & р'ка & barbă \\
\hline 3.068 & 'кисть' & киска, шака & mustachi/mustaț \\
\hline
\end{tabular}

Таблииза 2. Анкета «Части тела»

Всего из 127 пунктов анкеты информанты перевели 45 наименований, обозначающих самые общие понятия (такие как «язык», «рука», «волосы»), и не представили арумынских эквивалентов для более специфических понятий («мочка уха», «ушная раковина», «кадык» и др.).

При беседе с информантами по этнолингвистическому опроснику (см. ПлотниковА 2009) обнаружилось, что большинство терминов и лексем, связанных с народной обрядностью, называются по-македонски. Календарные термины и обрядовая лексика также ожидаемо оказались в большей степени славянскими, чем балканороманскими (см. Таблицу 3):

\begin{tabular}{|c|c|}
\hline Русский & Арумынский \\
\hline $\begin{array}{l}\text { 'Поминки. На следующий день идут... } \\
\text { на утреню, а оттуда на похороны, на } \\
\text { завтра идут...' }\end{array}$ & $\begin{array}{l}\text { Pomen. Alantă dzuă te hina s-duc pi prva } \\
\text { utrina, di carea va-l ăn'gropă } \breve{a}^{12}\end{array}$ \\
\hline $\begin{array}{l}\text { 'На Пасху мы красили яйца, на Вели- } \\
\text { кий Четверг готовили сладости.' }\end{array}$ & $\begin{array}{l}\text { Di Paşće vopscm ou, tu Veli četvrtak, va } \\
\text { s-adra cuziniacuri dulțe. }\end{array}$ \\
\hline ‘свидетель перед Господом’ & svedok pre Dumnidz( $\breve{a})$ \\
\hline $\begin{array}{l}\text { 'И когда начнется «Христос воскресе», } \\
\text { мы разбивали яйца в церкви, и затем } \\
\text { их ели.' }\end{array}$ & $\begin{array}{l}\text { ş-căn 'va zine Hristos voskrese, ne ciu- } \\
\text { cutem cu ouli la biserică, şi atunțel vă-s } \\
\text { măncam ouli. }\end{array}$ \\
\hline $\begin{array}{l}\text { ‘Благословенна ты в женах, и благо- } \\
\text { словен плон твоего чрева.’ }\end{array}$ & $\begin{array}{l}\text { Благословен' ешчи тине ла муљерле } \\
\text { ши благословен јасте фетуслу ди ата } \\
\text { стумахе. }{ }^{13}\end{array}$ \\
\hline
\end{tabular}

Таблица 3. Фрагменты нарративов - праздники и обрядность

12 Расшифровка произведена в соответствии с принятой в румынской диалектологии традицией со значительными упрощениями (например, не используется нестандартная диакритика, знак ударения, фонетические символы и др.).

${ }^{13}$ Из молитвы «Радуйся, Мария» (записан информанткой на македонской кириллице). 
Мы не проводили специального исследования календарной обрядности преспанских арумын, однако отметим, что семье информантов неизвестен балканороманский праздник Rusalii, при этом они отмечают типичный для южных славян праздник Слава.

В записанных в ходе экспедиции нарративах наблюдаются многочисленные случаи смешения кодов (code-mixing). Это явление понимается здесь в соответствии с определением П. Мэйскена - как случаи появления лексических или грамматических явлений двух языков в пределах одного предложения (code-mixing противопоставляется code-switching - переключению кодов), то есть осознанному переходу на другой язык или на субвариант того же самого языка в процессе речи, в зависимости от особенностей языковой ситуации) (см. MUYSKEN 2000). Чаще всего смешение кодов происходит на лексическом уровне. Забывая или не зная какое-либо слово на одном языке, двуязычный осознанно или неосознанно употребляет на его месте слово из второго языка. В Таблице 4 представлены примеры, иллюстрирующие подобные случаи:

\begin{tabular}{|l|l|}
\hline \multicolumn{1}{|c|}{ Русский } & \multicolumn{1}{|c|}{ Арумынский } \\
\hline $\begin{array}{l}\text { 'Сорок дней - это главные поминки по } \\
\text { усопшему.' }\end{array}$ & $\begin{array}{l}\text { Patrudzățde dzăle asta-i glavnto pomen } \\
\text { ti mortul. }\end{array}$ \\
\hline $\begin{array}{l}\text { 'Тогда не ели сладкое, только [еду], } \\
\text { приготовленную [букв. сделанную] } \\
\text { на воде.' }\end{array}$ & $\begin{array}{l}\text { Atunțel nu-s măca țiva purintă, samo } \\
\text { pi apă adrată. }\end{array}$ \\
\hline $\begin{array}{l}\text { 'Жених был в костюме, костюм доста- } \\
\text { вали, специально шили [букв. костюм } \\
\text { делался] к этому дню. Торжественно!’ }\end{array}$ & $\begin{array}{l}\text { Zetot era u custume, custume s`băga, } \\
\text { naročno se adra te ța dzuă. Svečeno! }\end{array}$ \\
\hline $\begin{array}{l}\text { 'Было... весело в доме, как сказать. } \\
\text { Все были веселые, с праздником, с...' }\end{array}$ & $\begin{array}{l}\text { Era... veselo vo kukjata, kako da rečem. } \\
\text { Era tuți haraokou, so veselba, so... }\end{array}$ \\
\hline
\end{tabular}

Таблица 4. Примеры смешения кодов у преспанских информантов

Что касается письменной речи на арумынском языке, то наши информанты используют македонский кириллический алфавит. Ниже представлены тексты молитв «Отче наш» (Рисунок 2) и «Радуйся, Мария» (Рисунок 3), записанные информанткой кириллицей и переписанные нами с использованием «румынской латиницы». Отметим, что это не единственные возможные способы записи текста на арумынском языке. Попытка стандартизации арумынского алфавита, предпринятая в конце 1990-х годов, привела к тому, что латиница без опоры на румынскую графику получила достаточно широкое распространение, однако так и не стала стандартом (об этом подробнее см. CUNIA 1999, FriedMAN 2001). Наряду с двумя вышеупомянутыми способами записи, встречается и запись с помощью греческого алфавита (FRIEDMAN 2001: 37). Среди греческих арумын (влахов) распространено представление о том, что «по-арумынски / влашски нельзя писать» (BARA et al. 2005: 17). 
(1) Молитва ал Думнизлу

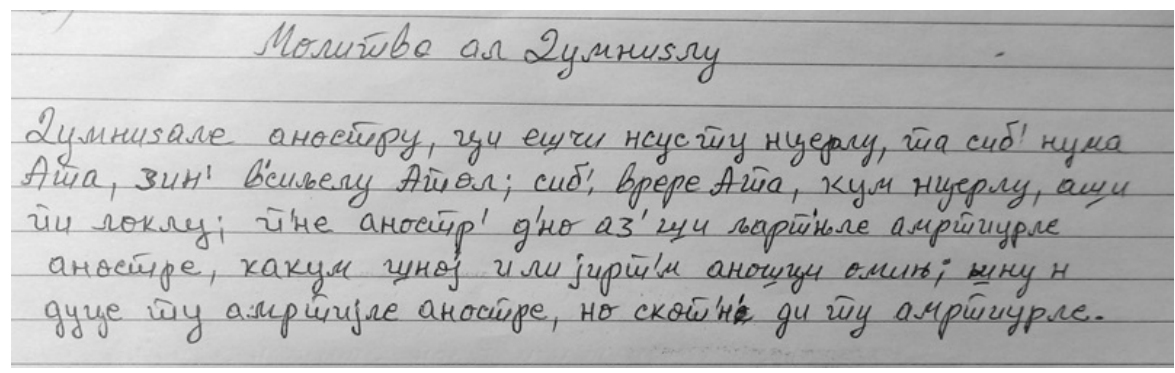

Рисунок 2. Молитва «Отче наш»

\begin{tabular}{|c|c|}
\hline Кириллица & $\begin{array}{c}\text { Письмо, основанное на графике } \\
\text { румынского языка }\end{array}$ \\
\hline $\begin{array}{l}\text { Думнияале аностру, ции ешчи нсус ту } \\
\text { нцерлу, та сиб'нума Ата, зин' в'сиьелу } \\
\text { Атол; сиб' врере Ата, кум нцерлу, аши } \\
\text { пи локлу; п'не аностр' д'но аз' ши љар- } \\
\text { m'юле амртиурле аностре, какум шној } \\
\text { и ли јирт'м аношци омињ; шну н дуцее } \\
\text { ту амртијле аностре, но скот'н'е ди } \\
\text { ту амртиурле. }\end{array}$ & $\begin{array}{l}\text { Dumnidzale anostru, ți eşci nsus tu nțer- } \\
\text { lu, ta sibă numa ata, zină văsiljelu atol; } \\
\text { sibă vrere ata, cum nțerlu, aşi pi loklu; } \\
\text { păne anostră dăno azăşi ljartănile amrti- } \\
\text { urle anostre, cacum şnoi i li iirtăm anoști } \\
\text { omini; şnu n duțe tu amrtiile anostre, no } \\
\text { scotănje di tu amrtiurle. }\end{array}$ \\
\hline
\end{tabular}

Таблица 5. Молитва «Отче наш», записанная информанткой из г. Ресен

(2) Ал'вдат кнтик ла Ст'м'рија Маре

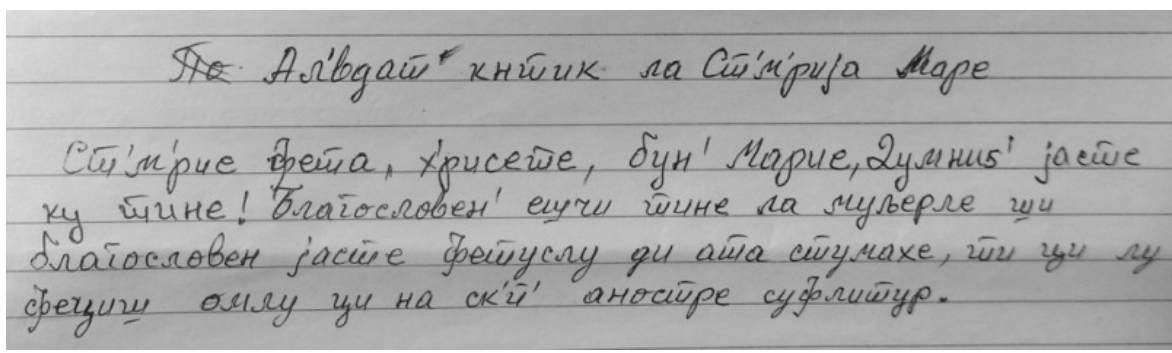

Рисунок 3. Молитва «Радуйся, Мария»

\begin{tabular}{|l|l|}
\hline \multicolumn{1}{|c|}{ Кириллица } & \multicolumn{1}{|c|}{ Письмо, основанное на графике } \\
румынского языка
\end{tabular}

Таблища 6. Молитва «Радуйся, Мария», записанная информанткой из г. Ресен 


\section{3. Заключение}

Таким образом, город Ресен, который еще до середины XX в. был одним из крупных центров компактного проживания арумын, к настоящему времени таковым уже не является: часть арумын покинула Преспу, часть - ассимилировалось с македонским населением, на что указывает тот факт, что еще есть жители города, говорящие на македонском языке, но хранящие память о своем арумынском происхождении.

«Градуальная форма» подобного перехода наблюдается в единственной семье, сохранившей арумынский язык на уровне старшего и среднего поколений, но не передавшей его младшему поколению. Согласно шкале GIDS (Graded Intergenerational Disruption Scale), разработанной Д. Фишманом для оценки состояния языков, находящихся под угрозой исчезновения (ее также называют шкалой уровней разрыва межпоколенческой передачи), арумынский язык в Преспе находится в данный момент на предпоследней, седьмой стадии. На этой стадии язык еще используется на ежедневной основе, но уже только старшими членами языкового сообщества (см. FISHMAN 2001). Полагаем, что в условиях, когда бо́льшая часть местных арумын покинула регион, а часть ассимилировалась с македонским населением, возможность того, что арумынский язык в Преспе переживет свое возрождение, невелика.

Несмотря на то, что арумынский является для каждого из информантов первым по порядку усвоения языком, доминирующим стал македонский то есть язык коммуникации с соседями, друзьями, клиентами, язык средств массовой информации, школы и церкви. Проблемы, связанные с механизмом изменения языковой ситуации, а также с основными причинами этого процесса, требуют дальнейшего исследования.

\section{Литература}

БРОмЛЕй и др. 1963 = БРомлЕй Ю. В. и др. (ред.) История Югославии. Т. 1. Москва: Издательство АН СССР, 1963.

ВЕЙСМАН 1899 = ВЕЙСМАН А. Д. Греческо-русский словарь. Санкт-Петербург, 1899.

ЗЛАТКОВСКАЯ 1951 = ЗЛАТКОВСКАЯ Т. Д. Мёзия в I и II в6. нашей эры (к истории нижнего Дуная в римское время). Москва: Издательство АН СССР, 1951.

Кукудис 2013 = Кукудис А. Ј. Власите: метрополи и дијаспора. Скопје, 2013.

Кънчов 1900 = Кънчов В. Македония. Етнография и статистика. София: Българското книжовно дружество, 1900.

МАКАРОВА $2014=$ МАКАРОВА А. Л. Анкета для изучения модальных и темпоральных категорий глагола в языках БЯС. Македонски јазик LXV. Скопје, 2014. 285-302.

МАКАРОВА 2016 = МАКАРОВА А. Л. Изоморфизм балканских глагольных систем (на материале арумынского, македонского и албанского диалектов региона Преспа). В кн.: Индоевропейское языкознание и классическая филология - ХХ. Материаль чтений, посвященных памяти профессора Иосифа Моисеевича Тронского. СанктПетербург: «Наука», 2016. 670-684. 
МАРковиќ 2007 = МАРковиќ М. Ароманскиот и македонскиот говор од охридскострушкиот регион во балкански контекст. Скопје: Македонска академија на науките и уметностите, 2007.

МДАБЯ 2009 = СоБОлЕВ А. Н. (ред.). Малый диалектологический атлас балканских языков. Серия лексическая. Т. 3. Животноводство. Санкт-Петербург: «Наука», München: Otto Sagner, 2009.

НАРумов 2001 = НАРумОв Б. П. Арумынский язык/диалект. В кн.: Языки мира. Романские языки. Москва: «Academia», 2001. 636-656.

НАСТЕВ 1988 = НАСТЕВ Б. Аромански студии. Прилози кон балканистиката. Скопје: Огледало, 1988.

ПлОтникОВА 2009 = ПлОтникОВА А. А. Материаль для этнолингвистического изучения балканославянского ареала. Москва: Институт славяноведения РАН, 2009.

ПоП-БоловАн 2005 = ПоП И. А., БолОВАН И. История Румынии. Москва: «Весь мир», 2005.

СЕЛИЩЕВ 1931 = СЕЛИЩЕВ А. М. Славянское население Албании. София: Македонский научный институт, 1931.

ШиРоковА 2005 = ШиРоковА А. В. От латыни к романским языкам. Москва: «ДобросвеТ-КДУ», 2005.

ШувАЛов 1998 = ШувАЛов П. В. Проникновение славян на Балканы. В кн.: Ocновь балканского языкознания. Языки балканского региона. Ч. 2. Славянские языки. Санкт-Петербург: «Наука», 1998. 5-28.

BARA et al. 2005 = BARA M., KAHL Th., SOBolev A. N. Южноарумынский говор села Турья (Пинд). Синтаксис. Лексика. Этнолингвистика. Тексты. München: Biblion, 2005.

CAPIDAN $2005=$ CAPIDAN Th. Aromânii. Dialectul Aromân. Bucureşti: Editura Fundației Culturale Aromâne „Dimândarea părintească“, 2005.

Cunia 1999 = Cunia T. On the Standardization of the Aromanian System of Writing. https://vulcanactiv.files.wordpress.com/2013/02/on-the-standardization-of-the-aromanian-system-of-writing.pdf.

Cvisić 1906 = CviJić J. Remarques sur l'ethnographie de la Macédoine. Annales de Géographie. Vol. 15. Num. 81. Paris, 1906. 249-266.

FisHMAN 2001 = FisHMAN J. A. Can Threatened Languages Be Saved? Bristol: Multilingual Matters, 2001.

FrIEDMAN 2001 = FrIEDMAN V. A. The Vlah Minority in Macedonia: Language, Identity, Dialectology, and Standardization. In: Nuoluoto J., Leiwo M., Halla-Aho J. (ed.) Selected Papers in Slavic, Balkan, and Balkan Studies. (Slavica Helsingiensa 21.) Helsinki: University of Helsinki, 2001. 26-50.

GoŁąB 1984 = GoŁĄB Z. The Arumanian dialect of Kruševo in SR Macedonia, SFR Yugoslavia. Skopje: MANU, 1984.

ЈовАНОВСКИ 2005 = ЈовАНОВСКИ В. Населбите во Преспа (местоположба, историјски развој и минато). Скопје: Ѓурѓа, 2005.

KAHL $2005=$ KAHL Th. Ethnische Gruppen in der Republik Makedonien und ihre demographischen Eingenschaften. In: SCHUBERT G. (Hrsg.) Makedonien. Prägungen und Perspektiven. (Forschungen zu Südosteuropa 1.) Wiesbaden: Harrassowitz, 2005. 57-81.

MAKAROVA 2016 = MAKAROVA A. Neka zapažanja o etnojezičkoj situaciji u dvojezičnim makedonsko-albanskim selima u regionu Prespa: fenomen Arvati. Studia Slavica Hung. 61 (2016): 115-130. 
Muysken $2000=$ Muysken P. Bilingual Speech. A Typology of Code-mixing. Cambridge: Cambridge University Press, 2000.

PAPAHAgi 1974 = PAPAHAgi T. Dicționarul dialectului aromân, general şi etimologic. Bucureşti: Editura Academiei Republicii Socialiste România, 1974.

RosetTI 1986 = RosetTI A. Istoria limbii române. De la origini până în secolul al XVIIlea. Bucureşti: Editura Ştiinţifică şi enciclopedică, 1986.

Saramandu-Nevaci 2014 = Saramandu N., Nevaci M. (ed.) Atlasul lingvistic al dialectului aromân. Bucureşti: Editura Academiei Române, 2014.

Weigand 1895 = Weigand G. Die Arumunen. Vol. 1. Leipzig: J. A. Barth, 1895.

WinNIFrith 1987 = WinNifrith T. J. The Vlachs. The History of a Balkan People. New York: Palgrave Macmillan, 1987. 